Article

\title{
A Prelude to Civil War: The Religious Nonprofit Sector as a Civil Means of Debate over Slavery, Christian Higher Education, and Religious Philanthropy in the Stone-Campbell Movement
}

\author{
Thad S. Austin
}

Lilly Family School of Philanthropy, Indiana University, Bloomington, IN 46202, USA; tsaustin@iupui.edu

Received: 8 May 2018; Accepted: 5 July 2018; Published: 1 August 2018

\begin{abstract}
This paper examines the role of Christian higher education and religious philanthropy in the debate over slavery prior to the Civil War. Competing religious views regarding slavery led to the founding of Indiana's abolitionist Butler University. The school's decision to brazenly support the cause of abolition directly conflicted with the leadership of The Disciples of Christ and mired the Indianapolis school in one of the most impassioned debates about the role of religious practice in civic life in the nineteenth century. In this case, the religious nonprofit sector functioned as battlefield upon which competing forces engaged in a form of civil conflict. An examination of the role of Butler University's philanthropic action provides fresh insight into the debate over slavery brewing on the eve of Civil War and the way individuals use philanthropic institutions, especially religious institutions, as a means to assert their values within society. Research for this study has employed primary archival research of documents held at Butler University, Christian Theological Seminary, and The Indiana Historical Society. The author has consulted period specific newspapers, journals, and handwritten documents. The author has also employed a host of secondary resources ranging from academic journals and religious histories to personal interviews and literature on the State of Indiana.
\end{abstract}

Keywords: religion; higher education; philanthropy; Civil War; abolition; slavery

\section{Introduction}

Leading up to the civil war, slavery fomented debate within parochial institutions such as North Western Christian University, renamed as Butler University in 1877. The abolitionist founders of this academic institution were members of The Disciples of Christ-a Protestant denomination also known as the "Christian Church" or the "Stone-Campbell Movement." These institutional leaders insisted that North Western Christian University be established far from the taint of slavery. However, these ideals clashed with the more moderate leadership of their denomination. Emerging from American Presbyterianism during the Second Great Awakening, The Disciples of Christ sought to restore Christian unity by abandoning denominationalism and sectarian creeds. Patriarch of the Stone-Campbell Movement, Rev. Alexander Campbell considered slavery a political, not moral, issue and advocated for Christian unity. Butler University's founders vehemently disagreed, and the two sides used the religious nonprofit sector as an arena to engage in battle over the theological, political, and social efficacy of slavery in America. 
Robert Payton described philanthropy as a form of "moral discourse" that thrusts ethics between politics and the free market. ${ }^{1}$ In this case, North Western's decision to brazenly support the cause of abolition mired the Indianapolis school in one of the most impassioned debates about the role of religious practice in civic life in the nineteenth century. Rooting the school in principles of diversity and inclusion from its inception, the founders of North Western Christian University used the religious nonprofit sector and the establishment of the school itself to project their moral commitments. An examination of the role of religious philanthropy in Butler University's founding provides insight into the debate over slavery brewing on the eve of Civil War and a fresh understanding of the way individuals use institutions as a means to assert their values within society.

\section{The Disciples of Christ: Religious Higher Education and Divergent Theologies of Political Discourse}

On Friday morning, 26 June 1856, The Indianapolis Daily State Sentinel published a letter to the editor written by a concerned citizen. The anonymous author desired to bring attention to the controversial social stance that North Western Christian University's ex-officio President, Elder John Young, had taken the previous Saturday at a raucous political rally. Writing to the "thinking portion [of the Indianapolis] community[,]" the incensed author described how Elder Young publicly changed his political affiliation to align with the abolitionist Republican party and shockingly endorsed one of its candidates for office. The citizen claimed that Elder Young-a prominent Indianapolis lawyer, scholar, and Disciples of Christ preacher-threw "off his ministerial robes[,]" "lost sight of the high calling[,]" and began "stumping politics on the streets. . .." Concluding his article, the author asked, "Can it be that the Christian pulpit is to be made the shrine of politics? Can it be that N. W. C. University is to be the refuge of Abolitionism?"2 History would answer the exasperated citizen's question in the affirmative.

Less than a year earlier, North Western Christian University-now Butler University and Christian Theological Seminary_began operation "with a janitor, two professors, no president, and a mortgage." ${ }^{3}$ Ovid Butler and other prominent members of The Disciples of Christ in Indiana founded the school with a firm commitment to equality rooted in Christian theology. These founders believed in abolition and education without regard for gender or race, courageous ideals in antebellum America. ${ }^{4}$

By the early 1850s, most major denominations-including the Presbyterians, Methodists, Baptists, Catholics, and Quakers—-had established one or more colleges in the State of Indiana. The Disciples of Christ, however, were noticeably missing educational pioneers. Although The Disciples possessed one of the largest membership rolls of any Christian denomination in the state, George Waller has called The Disciples of Christ "a latecomer" among the denominations founding colleges in Indiana during the antebellum era. ${ }^{5}$ The hesitancy of The Disciples of Christ to establish a school in Indiana resulted from the controversy surrounding the topic of slavery and fervent beliefs about education expressed by the denomination's patriarch, Rev. Alexander Campbell.

Campbell believed that Bethany College, which he himself established for the Stone-Campbell movement in slave holding Virginia (now West Virginia), was the best place for his followers to receive a university education. Campbell filled the pages of The Millennial Harbinger-his monthly journal distributed to his followers across America-with an elaborate philosophy of Christian education touting the benefits of his university. ${ }^{6}$ Campbell believed that the goal of education was not simply

1 (Payton 1988) R.L. Payton. Philanthropy: Voluntary Action for the Public Good (American Council on Education/Macmillan Publishing Company, 1988).

(North-Western Christian University 1856a) “North-Western Christian University,” Daily State Sentinel, 26 June 1856, p. 3. (Waller 2006) Waller, George M., Butler University: A Sesquicentennial History (Indiana University Press, 2006), p. 22.

(Butler University n.d.) “Butler University: History \& Traditions," Butler University. Available online: https:/ / www.butler. edu/history-traditions (accessed on 1 July 2018).

5 (Waller 2006) Waller, Butler University: A Sesquicentennial History, p. 1.

6 (Fife 1960) "Bethany was a corporate expression of the educational philosophy of Alexander Campbell. ..." Robert Fife, "Alexander Campbell and the Christian Church in the Slavery Controversy" (Dissertation Indiana University, 1960), p. 208. 
instruction but rather to develop the "sensibilities of the soul" with the Bible as the foundation for all true learning. ${ }^{7}$ In creating Bethany College in 1840, Campbell envisioned that "all the sections of the 'brotherhood'" could come together for a single, unified education. ${ }^{8}$

In addition to his educational beliefs, Campbell considered slavery a political issue, not a moral issue. While he personally disapproved of slavery, he could not find Biblical support to oppose the practice within society. When congress passed the Fugitive Slave Act of 1850 that aided Southern slaveholders in recapturing runaway slaves, Campbell defended his position writing:

Some Christians are conscientious about giving up a servant to his master. So was not Paul, when he sent the runaway Onesimus home to his master? . . . [A]llegiance . . . to the laws of the United States, is, by general concession, both political and moral. . . . The law in question, for reclaiming fugitive servants, is, to any ordinary mind, most obvious and perfectly constitutional. . . . ${ }^{9}$

For the sake of Christian unity, Campbell urged his followers to remain neutral on the controversial topic of slavery. He believed that Bethany College was uniquely suited for this purpose. Campbell wrote that Bethany College, "almost within sight of two free States," is "located in a county of as pure air . . . as any in America. . . . amidst a population free from free soil and slave soil, or any other political hobby, as any county in Indiana." 10

Most members of The Disciples of Christ agreed with Campbell's moderate position. ${ }^{11}$ Still, others vehemently disagreed both with Campbell's belief about the efficaciousness of Bethany College and his public theology of slavery. A member of The Disciples of Christ during this period, Corydon Fuller noted that Campbell's response to the Fugitive Slave Act was not sufficiently anti-slavery to please his members in the Midwest. Furthermore, Fuller said, "Bethany was on soil cursed by slavery."12 The leaders of The Disciples of Christ in Indiana agreed. They clamored for a university of their own to be established on free soil. Founders of North Western Christian University brazenly insisted that they establish a university in Indiana with a distinctive commitment to abolition. ${ }^{13}$

\section{Contextual Considerations: The Role of American Religion and Antebellum Politics}

The power of religion during the antebellum era cannot be overstated..$^{14}$ Religion was America's backbone. ${ }^{15}$ Congregations and religious societies received income almost at parity with the annual receipts of the federal government, clergy outnumbered U.S. military personnel two to one, and the number of individuals worshipping on any given Sunday exceeded the total number of votes cast in the 1860 presidential election by more than three fold. ${ }^{16}$ Recounting his experiences traveling through America, Alexis de Tocqueville observed the direct and indirect influences of religion on

7 (Campbell et al. 1850) Campbell, A. et al., The Millennial Harbinger, ed. A. Campbell, vol. 7, Series 3 (A. Campbell, 1850), 7, p. 18.

8 (Fife 1960) Fife, "Alexander Campbell and the Christian Church in the Slavery Controversy," p. 209.

9 (Campbell et al. 1851) A. Campbell, W.K. Pendleton, and C.L. Loos, The Millennial Harbinger, vol. 1 (W.K. Pendleton, 1851), 29-30. See also D.D. Cummins, The Disciples Colleges: A History (CBP Press, 1987), p. 53.

10 (Campbell et al. 1851) Campbell and Pendleton, The Millennial Harbinger, 4, p. 43.

11 (The Stormy Question n.d.) “The Stormy Question: Christian Churches and the Slavery Issue," Disciples of Christ Historical Society. Available online: http:/ / portal.sliderocket.com/AQRSO/The-Stormy-Question-REV-NAV. Slide 66 of 133 (accessed on 1 July 2018)

12 (Fuller 1887) Fuller, Corydon E. Reminiscences of James A. Garfield: With Notes Preliminary and Collateral (Standard Publishing Company, 1887), p. 29.

13 (Cummins 1987) Cummins, D. Duane, The Disciples Colleges: A History (CBP Press, 1987), p. 53-54.

14 (Carwardine 1993) According to Richard Carwardine, more than forty percent of the American population were Evangelicals during the mid 1850s. See Richard Carwardine, Evangelicals and Politics in Antebellum America (University of Tennessee Press, 1993), p. 44.

15 (Miller et al. 1998) Miller, Randall M., Harry S. Stout, and Charles Reagan Wilson, eds. Religion and the American Civil War (New York: Oxford University Press, 1998), 5. (Nevins 1938) The invertebrate imagery references Allan Nevins, The Gateway to History (New York: D. Appleton-Century Company, 1938), p. 272.

16 (Noll 2006) Noll, Mark A., The Civil War as a Theological Crisis (University of North Carolina Press, 2006), p. 12. 
American private and public life. Noticing this powerful "alliance" and describing the sheer number of American sects as "innumerable," de Tocqueville indicated, "Every religion [in America] is to be found in juxta-position to a political opinion. . .."17

In the antebellum period, religious advocacy had railed against drunkenness and prostitution. ${ }^{18}$ However, a series of events took place that redirected the attention of America's religious advocacy. Timothy Wesley has written:

Driven by the perceived unrighteousness of the U.S.-Mexican War, the insults to conscience threatened by the Fugitive Slave Act, and the proslavery effrontery of the Kansas-Nebraska Act, more and more preachers within established denominational traditions took to their pulpits and their writing parlors to indict the evils of slavery. ${ }^{19}$

There is no doubt that religion played a predominant role in the debate over slavery leading up to the Civil War. ${ }^{20}$ James McPherson has described religion as "central to the meaning of the Civil War" because of religion's profound influence on those who experienced the conflict first hand. ${ }^{21}$ For this reason, Mark Noll has proposed that the Civil War was essentially a "theological event," and Timothy Wesley has referred to the conflict as a "great theological crisis."22 Between 1837 and 1854, the Presbyterian, Methodist, and Baptist denominations fractured over the issue of slavery. ${ }^{23}$ With their emphasis on Christian unity, The Disciples of Christ had avoided such schism.

While historians immediately following the Civil War portrayed Indiana as staunchly supporting the Union's cause, division existed in the state regarding the concept of slavery and the role of abolition. Because Indiana was settled primarily by individuals from slave-holding states, some Indiana residents sympathized with their southern neighbors. Although the Northwest Ordinance of 1787 prohibited slavery in Indiana, citizens worked around the law by forcing African Americans into indentured service for periods exceeding normal life expectancy. An opponent of slavery in Indiana, John Badollet voiced opposition: "The introduction of Slavery [sic] into this territory continues to be the Hobby horse of the influential men here." 24 The 1810 census recorded 237 slaves and 393 free blacks in Indiana. Historian James Madison explained: “Few Hoosiers defended slavery. . . . At the same time, few whites in pioneer Indiana proposed to interfere in the South's peculiar institution. Even fewer proposed to alter the radical inequalities within Indiana." 25

Racial tensions were so severe in Indiana that a mob beat an African American to death on the streets of Indianapolis in $1845 .{ }^{26}$ Five years later at the 1850 state constitutional convention, legislators made a proposal to prevent African American migration to Indiana. ${ }^{27}$ The proposal required all African Americans currently living in the state to register with their county clerk and barred future freedmen from moving to the state. The measure passed overwhelmingly. In Marion County (the location of Indianapolis), the vote was 2509 to $308 .{ }^{28}$ Furthermore, the presidential election

17 (De Tocqueville 1839) Tocqueville, Alexis de, Democracy in America, trans. Henry Reeve (New York: George Adlard, 1839), 299 , p. 302.

18 (Miller et al. 1998) Miller, Stout, and Wilson, Religion and the American Civil War, p. 5.

19 (Wesley 2013) Wesley, Timothy L., The Politics of Faith during the Civil War, (Baton Rouge: Louisiana University State Press, 2013), p. 8.

20 (Miller et al. 1998) Miller, Stout, and Wilson, Religion and the American Civil War, p. 4.

21 (McPherson 1997) McPherson full quote reads: "Religion was central to the meaning of the Civil War, as the generation that experienced the war tried to understand it. Religion should also be central to our efforts to recover that meaning." James M. McPherson, "Afterward," in Religion and the American Civil War, ed. Randall M. Miller, Harry S. Strout, and Charles Reagan Wilson (New York: Oxford University Press, 1997), 63.

22 (Noll 2006) Noll, Mark A., The Civil War as a Theological Crisis, 17. Wesley, The Politics of Faith during the Civil War, p. 10.

23 (Wesley 2013) Wesley, Timothy L, The Politics of Faith during the Civil War, p. 9.

24 (Madison 2014) Madison, James H., Hoosiers: A New History of Indiana (Indiana University Press, 2014), pp. $46-47$.

25 (Madison 2014) Madison, James H., Hoosiers: A New History of Indiana, p. 105.

26 (Martin 1947) Martin, John Bartlow, Indiana: An Interpretation (Indiana University Press, 1947), p. 58.

27 (Martin 1947) Martin, Indiana: An Interpretation, p. 58.

28 (Bodenhamer and Barrows 1994) Bodenhamer, David J. and Barrows, Robert G., The Encyclopedia of Indianapolis (Indiana University Press, 1994), p. 265. 
of 1861 further confirmed Indiana's divided spirit. Although Abraham Lincoln carried Indiana, the victory was not decisive. Stephen Douglas polled well, and Breckenridge-the pro-Slavery Democratic candidate-received 12,000 votes. When President-Elect Lincoln visited Indianapolis on his way to his inauguration, a host of detractors greeted him. Jeannette Covert Nolan described the gathering: "Of the thousands massed solidly around the hotel, jamming the intersection of Washington and Illinois Streets, all were not cordial. On the contrary, many were merely curious and as many more frankly hostile." 29

\section{Faith Demanding Action: Political Theology Leads to the Founding of an Institution of Religious Higher Education}

Citizens most radically opposed to slavery were known as abolitionists. Madison has revealed that the abolitionist movement "remained weaker in Indiana than in perhaps any other northern state." ${ }^{30}$ This was especially true in Indianapolis, which possessed a large southern population. ${ }^{31}$ Because most members of the Disciples of Christ supported Alexander Campbell's moderate position on slavery, abolitionists represented a minority in the denomination. ${ }^{32}$ Breaking this stereotype on both accounts, Ovid Butler-a resident of Indianapolis and a member of the Disciples of Christ—was one of Indiana's leading abolitionists.

The son of a converted Disciples of Christ pastor, Butler possessed a deep faith and social conscience, believing that Christian conviction demanded action. When it came to the topic of slavery, Butler failed to see how the practice was compatible with Christianity. He believed that slavery was not an abstract idea but a sin against God and humanity. As he said, "No one but God can own a man." ${ }^{33}$ Accordingly, Butler financially backed two abolitionist newspapers, and when his Democratic Party did not take a stand on slavery, he helped organize the Free Soil Party, a short lived (1848-1852), single-issue political platform opposing the expansion of slavery to western territories and advocating the fair distribution of land.

Historians have argued that, unlike the abolitionist movement, the Free Soil Party's opposition to slavery was not on the whole motivated by morality. ${ }^{34}$ While some members of the party such as Ovid Butler also championed the abolitionist cause on moral grounds, ${ }^{35}$ the Free Soil base supported economic and political egalitarianism that preserved, as one newspaper of the time put it, "the freedom of white men, as well as that of negroes." 36 The expansion of slavery threatened the social mobility and political power of non-aristocratic white Americans. ${ }^{37}$ Thus, antislavery and anti-black views coexisted within the movement. A product of his time, Butler possessed both ardent abolitionist beliefs and also a progressive-ambivalence towards racial issues more broadly: To support abolition was not to believe in universal racial equality. ${ }^{38}$

29 (Nolan 1943) Nolan, Jeannette Covert, Hoosier City (J. Messner, Incorporated, 1943), pp. 130-31.

30 (Madison 2014) Madison, James H., Hoosiers: A New History of Indiana, p. 109.

31 (Bodenhamer and Barrows 1994) Bodenhamer and Barrows, The Encyclopedia of Indianapolis, p. 264.

32 (Foster 2004) Foster, Douglas A., The Encyclopedia of the Stone-Campbell Movement (Eerdmans Publishing Company, 2004$),$ p. 2.

33 (Smith et al. 1863) Smith, Jeremiah; Butler, Ovid, and Wiley, Thomas, Is Slavery Sinful? (Indianapolis: H. H. Dodd \& Co., Printers, 1863), pp. 123-24.

34 (Earle 2005) Earle, Jonathan H., Jacksonian Antislavery and the Politics of Free Soil, 1824-1854 (University of North Carolina Press, 2005), p. 197.

35 (Pierson 1993) For a discussion of abolition in the Free Soil Movement, see Michael D. Pierson, "Between Antislavery and Abolition: The Politics and Rhetoric of Jane Grey Swisshelm," Pennsylvania History: A Journal of Mid-Atlantic Studies 60, no. 3 (1993): pp. 305-21.

36 (Earle 2005) qtd. in Earle, Jacksonian Antislavery, p. 197.

37 (Foner 1995) See Foner, Eric, Free Soil, Free Labor, Free Men: The Ideology of the Republican Party before the Civil War With a New Introductory Essay. (Cary: Oxford University Press, 1995).

38 (Seay 2015) Butler believed in a hierarchy of races. For example, when the African American Sunday School class at Butler's church grew to an "alarming" size, an effort was made to segregate the races by establishing another church for African Americans. Dr. Scott Seay, interview by Thad Austin, 1 December 2015. 
After retiring from his lucrative law practice, Butler devoted himself to public service and philanthropic action. Abolition, education, and The Disciples of Christ served as his greatest causes. In founding North Western Christian University, Butler brought these passions together. The name of the school was a tribute to the Northwest Ordinance of 1787. Just as the Northwest Ordinance had prohibited slavery in the territory north of the Ohio River, Butler believed that North Western Christian University should be a herald of abolition and social equality. ${ }^{39}$ Once the Indiana General Assembly approved North Western's charter on 15 January $1850,{ }^{40}$ the school began raising money for construction and operation. For its fundraising efforts, the board enlisted the help of John O'Kane-a popular Disciples of Christ preacher with piercing eyes, a commanding presence, and a witty, engaging personality. ${ }^{41}$ The board gave $\mathrm{O}^{\prime}$ Kane the goal of $\$ 75,000$, a sum he was able to raise from commitments from 300 churches in just eighteen months.

Likely aware of the progress of North Western Christian University, Campbell wrote an extended, two-part exposition on education in The Millennial Harbinger. In April of 1850, Campbell disparaged any educational endeavor separated from the teachings of the Bible as "rather heathenish than either Christian or philosophical." 42 Inspired by Campbell's essay, Butler responded with a congenial letter to Campbell published in The Millennial Harbinger less than a month later. Butler extoled the good news of North Western's progress, writing, "[W]e have hopes that we shall succeed in building up an institution creditable both to the church and to the country." ${ }^{\prime 3}$ In the letter, Butler assured Campbell his intentions were consistent with Campbell's own view of education and even attempted to convince Campbell of the efficacy of a school in Indiana given the increasing number of Disciples living in the area. Butler asserted that Campbell, who relied on the south as the primary means of support for Bethany College, was influenced by the politics of the time. Accordingly, Butler wrote that "the north-western brethren ... will manifest their liberality especially in favor of an institution ... built up amongst them, and sustained by them." ${ }^{44}$

Responding in a scathing open letter printed in The Millennial Harbinger, Campbell stated that Butler's "worldly interests" in establishing North Western Christian University were "essentially local, sectional, and selfish." ${ }^{45}$ To these reproachful qualities, Campbell contrasted the true virtues of Christian education which are not geographic or sectarian pursuits. Campbell asserted that Bethany College was not founded out of a commitment to a particular social stance but out of a commitment to literature, science, and religion. Campbell expressed his regrets that anyone should be associated with a divisive, political project like North Western Christian University. To his detractors opposing Bethany College's location in a slave state, Campbell argued that Bethany was situated in one of Virginia's free counties and in a free section of the state. He wrote: "The county of Brooke has not a single slave, except some six or seven superannuated old men and women. And these neither humanity nor religion, neither law nor gospel, would emancipate." ${ }^{46}$

Only months after writing these words, Campbell embarked on his first tour of Indiana, attempting to raise financial support to endow an "Indiana" Chair of Ancient Languages at Bethany College. Such was the internecine strife: After Campbell wrote of his displeasure with North Western

39 (Benton 1908) Benton, Allen R., "Early Educational Conditions and Founding of a Denominational College," The Indiana Quarterly Magazine of History (1908): p. 15.

40 (Kondelik 1993) The resolution dated 15 January 1850 reads, "The said Board of Directors are hereby authorized and empowered ... to select and locate, in the City of Indianapolis, or in its vicinity, a suitable and proper site and location for the buildings of the institution, and to purchase and procure the same with such adjacent grounds as they may think proper ... to establish the 'Northwestern Christian University.'” See Kondelik, "Butler University and the Dream of Distinction," p. 10.

41 (Waller 2006) Waller, Butler University: A Sesquicentennial History, pp. 11-12.

42 (Campbell et al. 1850) Campbell et al., The Millennial Harbinger, 7, p. 174.

43 (Campbell et al. 1850) Ovid Butler qtd. in Campbell et al., The Millennial Harbinger, 7, p. 330.

44 (Campbell et al. 1850) Campbell et al., The Millennial Harbinger, 7, p. 330.

45 (Campbell et al. 1850) Campbell et al., The Millennial Harbinger, 7, p. 330.

46 (Campbell et al. 1850) Campbell et al., The Millennial Harbinger, 7, p. 333. 
Christian University's progress, he visited Indiana with the intent to create an Indiana Chair at his Virginia college.

While Campbell was traveling throughout the region soliciting donations for Bethany's new endowed chair program, some churches declined Campbell's request for contributions. Inquiring why they refused to support his school, Campbell discovered that O'Kane had traveled ahead of him visiting each of the locations on Campbell's circuit. To make matters worse, $\mathrm{O}^{\prime}$ Kane included the topic of slavery and abolition in his appeal. Campbell quoted O'Kane as saying, "Christians living on free soil, should not cooperate with Christians living on slave soil, in any seminary of learning." 47 Campbell scoffed that O'Kane's unjustifiable actions had sown seeds of mistrust within the church and described $\mathrm{O}^{\prime}$ Kane's behavior as inherently political and characteristically un-Christian. ${ }^{48}$

In response, the North Western Board of Directors asserted that they never agreed to support or raise money for a position at Bethany College. They denied the political nature of their decision to establish their school in Indianapolis and concluded their remarks by stating that North Western Christian University's location in a free state meant that the "students attending it would not be brought into contact with habits and manners that exist in populations where slavery exists." ${ }^{49}$ This concluding statement directly attacked Campbell and Bethany College.

The controversy with Campbell only motivated North Western's founders. ${ }^{50}$ On Thursday, 1 November 1855, North Western Christian University opened. The university enrolled 113 students during its first year of operations. Yet, Campbell saw no benefit in the school. Just months before North Western Christian University opened, Campbell accused Butler of "pride and secular ambition." 51 Campbell wrote: "[The opening of North Western Christian University] is, and will long be, a proud monument of free soil jealousy, magnanimity, and generosity. . . ."52

The rift between Campbell and North Western Christian University would take years to heal, and an event took place in 1855, the same year as the school's opening, that only exacerbated the wounds.

\section{Expulsion and Admittance: Student Protests as Public Debate Reaches a Fever Pitch}

Campbell believed university life was to be focused on religion and education, not on contentious political issues. Bethany's code of conduct formally restricted student involvement in such divisive social topics. Southerners who favored the institution of slavery constituted a majority of Bethany's student body, but a vocal minority of students from northern states began to advocate for abolition on the school's campus. Many of these abolitionists were part of the Adelphian Society, a group of ministers in training. Campbell described the anti-slavery students as zealous "inexperienced young men, in the agitation of the vexed question of slavery[, . . . who seem to have come, rather in the spirit of patriots and social reformers, than that of students." ${ }^{53}$ The two sides debated the topic of slavery outside of the classroom from time to time. However, when Campbell came out in favor of the Fugitive Slave Act, some of Bethany's professors allowed the school's pro-slavery students to celebrate. ${ }^{54}$ The students who supported abolition expressed their displeasure but were silenced by the administration and taunted by other students. ${ }^{55}$

\footnotetext{
(Campbell et al. 1854) Campbell and Pendleton, The Millennial Harbinger, 4, p. 42.

(Campbell et al. 1854) The Millennial Harbinger, 4, p. 42.

(Cummins 1987) Cummins, The Disciples Colleges: A History, p. 52.

(Hobbs 1899) Hobbs, Robert Wilson, The Drift (Indianapolis: The Senior Class of Butler College 1899), p. 10.

(Campbell et al. 1855) Campbell, Pendleton, and Loos, The Millennial Harbinger, 5, p. 218.

(Campbell et al. 1855) Campbell et al., The Millennial Harbinger, 5, 218.

(Campbell et al. 1856) Campbell et al., The Millennial Harbinger, vol. 6 (W.K. Pendleton, 1856), p. 54.

54 (Thomas 2005) Thomas, "Slavery, a Colossal Crime: A Religious and Political Biographical Thesis of Ovid Butler (1801-1881)," p. 62.

55 (Waller 2006) Waller, Butler University: A Sesquicentennial History, p. 18.
} 
The Adelphian Society took turns preaching at the village church on Sunday nights. On one of those occasions, a member sympathetic to the abolitionist cause, Mr. Way, preached a sermon entitled "The True Principles of Liberty" in which he advocated the merits of abolitionism. Although Campbell claimed that two-thirds of the students remained well-mannered during the service, many of the pro-slavery students began hissing, pounding the floor with their feet and canes, and eventually walked out of the church to hold a demonstration outside. ${ }^{56}$ Tension grew. A group of eighty pro-slavery students issued a threat to Mr. Way to cease propagating abolitionism.

The anti-slavery students reacted by boycotting their classes. They demanded that the school's administration permit a proper debate on slavery and also discipline the students who walked out of the village worship service. In response, the faculty issued the abolitionist students a firm ultimatum: Return to class or face expulsion. When five of the abolitionist students refused to comply, they were summarily expelled. A handful of other students left with them. Campbell justified the school's actions explaining that the expelled students were "under the wicked spirit of politico-religious fanaticism, and a puerile itching for even infamous notoriety." 57

Most academic institutions of this time had a reciprocal understanding regarding disciplinary procedures. A given university would respect and uphold another school's decisions, especially if a student were dismissed. However, upon expulsion, the abolitionist students applied to North Western Christian University and were promptly admitted. The two schools exchanged a tense series of letters, each accusing the other of impropriety. The event made national and international headlines. ${ }^{58}$ Indiana newspapers reported the story in detail. The Daily State Sentinel read:

The 'North-western Christian University' at Indianapolis appears to have been converted into an institution for the propagation of Abolitionism. The leading spirits among the students are the young men who were expelled from Bethany College for preaching incendiary Abolition doctrines to the slaves in Virginia, and the President, Prof. Young, made a speech at a Fremont gathering the other night. ${ }^{59}$

The speech that the article references was the one in which North Western's President John Young, a long-established Democrat, came out publicly as an abolitionist Republican. Some of the residents in Indianapolis were incensed by Young's actions. A concerned Indianapolis citizen wrote an anonymous letter to the editor haranguing Young, saying that he made:

an exhibition of himself on the street, before ... that fanatical band of sectionalists. . . Can it be that . . . those fast young fugitives from 'Bethany College,' have swayed the mind of one, who was once so truly great, moral and religious, as Elder John Young? . . [ [H]e has thrown off his ministerial robes; lost sight of the high calling and . . . merged all in that foul and corrupt clan . . of Abolition leaders. 60

The debate surrounding slavery had divided The Disciples of Christ and mired North Western Christian University's founding in controversy.

\section{Conclusions}

The social tension that gave rise to the establishment of Butler University also reflected a theological debate about the role of religion in public life, especially with regard to controversial social topics. While Alexander Campbell firmly believed that politics had no place in either religion

56 (Garrett 2002) Garrett, Leroy, The Stone-Campbell Movement: The Story of the American Restoration Movement (Abilene, TX: College Press Pub., 2002), p. 342.

57 (Campbell et al. 1855) Campbell, Pendleton, and Loos, The Millennial Harbinger, 5, p. 226.

58 (Garrett 2002) The story was carried by the New York Tribune, The Louisville Journal, and two papers in Glasgow, Scotland. See Garrett, The Stone-Campbell Movement: The Story of the American Restoration Movement, p. 341.

59 (North-Western Christian University 1856b) "North-Western Christian University," Daily State Sentinel, 1 July 1856, p. 2.

60 (Waller 2006) Waller, Butler University: A Sesquicentennial History, p. 3. 
or education, others like Ovid Butler believed that Christianity demanded social engagement. For Butler, social conscience was not merely a matter of personal conviction. He believed that following the will of God would lead to action, advocacy, and progress. ${ }^{61}$ In this way, the religious faithful of the antebellum period used the nonprofit sector as an instrument to establish their values in society. ${ }^{62}$

More than an expression of personal conviction, however, the institution of religious higher education, established through this value-laden debate, became itself a champion of social ideals. Campbell saw North Western Christian University as a lifeless "monument of free soil jealousy." 63 In reality, however, the establishment of the school provided an active platform for debate to ensue. At his seventieth birthday, Butler reflected on his personal goal for the establishment of the university as a religious "advocate and exponent of the common and equal rights of humanity." ${ }^{\prime 64}$ In contrast to Campbell, Butler saw the school as the "advocate" itself. These two men envisioned the nonprofit sector serving different functions. Campbell believed religious higher education was a passive conduit for Christian unity, while Butler believed the nonprofit sector could be a philanthropic weapon to influence religious and social politics. Indeed, the physical and philosophical presence of North Western Christian University stretched the socio-political boundaries of a denomination, inspired young people to action, and fostered social equality for years to come. ${ }^{65}$

Historian Kevin Robbins has noted that within Western civilization, the nonprofit sector can serve as a battlefield upon which competing forces engage in a "kind of civil war by other means." 66 Butler University's distinctive commitment to abolition provides insight into the brewing debate over slavery that ensued in America on the eve of Civil War. Within less than six years of North Western's opening, the issue of slavery drove the nation into its bloodiest conflict. ${ }^{67}$ In the case of North Western Christian University, the nonprofit sector functioned as a front line for these opposing ideological forces to muster support, and in the process, a religious institution of higher education became an instrument of political warfare. The conflict between Butler and Campbell over the issue of abolition led to the establishment of a nonprofit, educational institution and served as a civil prelude to the national conflict that followed.

Funding: This research received no external funding.

Acknowledgments: The author wishes to thank Scott Seay, Associate Professor of the History of Christianity at Christian Theological Seminary, whose wise counsel and generous access to archival documents made the research and writing of this manuscript possible.

Conflicts of Interest: The author declares no conflict of interest.

\section{References}

Benton, Allen R. 1908. Early Educational Conditions and Founding of a Denominational College. The Indiana Quarterly Magazine of History 13-17.

Bodenhamer, David J., and Robert G. Barrows. 1994. The Encyclopedia of Indianapolis. Bloomington: Indiana University Press.

61 (Butler n.d.) In addressing a group of North Western Christian University students, Ovid Butler expressed his understanding of rational law. He said, "Law in its most comprehensive sense is the requirement of being, motion and action. ... That intentional requirement . . . by which the order and harmony of matter . . . are proscribed . . . is the Will of God." See Ovid Butler, "Utitiled, Ovid Butler an Address to Students on the Subject of Law," (MC 19, "North Western Christian University," Series 4, Folder 4, held in the Special Collections at Christian Theological Seminary, Indianapolis, Indiana, n.d.), p. 3.

62 (Watkins 2001) Watkins, Keith, Christian Theological Seminary, Indianapolis: A History of Education for Ministry, p. 1.

63 (Campbell et al. 1855) Campbell et al., The Millennial Harbinger, 5, p. 218.

64 (Benton 1908) Benton, "Early Educational Conditions and Founding of a Denominational College," p. 16.

65 As an example, Butler University was one of the first schools in America to admit women on an equal basis as men.

66 (Robbins 2006) Robbins, Kevin C., "The Nonprofit Sector in Historical Perspective: Traditions of Philanthropy in the West" in The Nonprofit Sector: A Research Handbook, ed. W.W. Powell and R. Steinberg (Yale University Press, 2006), 25-26.

67 (Fuller 1887) As Corydon Fuller reflected in 1887, “It must be remembered that the fires were smoldering in 1850 and 1851 , which ten years later wrapped the whole nation in the flames" of conflict. See Fuller, Reminiscences of James A. Garfield: With Notes Preliminary and Collateral, 29. 
Butler, Ovid. n.d. Untitled, Ovid Butler an Address to Students on the Subject of Law. MC 19, North Western Christian University, Series 4, Folder 4, held in the Special Collections at Christian Theological Seminary, Indianapolis, Indiana.

Butler University. n.d. Butler University: History \& Traditions. Available online: https://www.butler.edu/ history-traditions (accessed on 1 July 2018).

Campbell, A., William Kimbrough Pendleton, and Charles Louis Loos. 1851. The Millennial Harbinger. Vol. 1: W.K. Pendleton.

Campbell, A., W.K. Pendleton, R. Richardson, and A.W. Campbell. 1850. The Millennial Harbinger. Series 3. Edited by A. Campbell. Vol. 7: A. Campbell.

Campbell, Alexander, William Kimbrough Pendleton, and A.W. Campbell. 1854. The Millennial Harbinger. Series 4. Edited by A. Campbell. Vol. 4: A. Campbell.

Campbell, Alexander, William Kimbrough Pendleton, and A.W. Campbell. 1855. The Millennial Harbinger. Vol. 5: W.K. Pendleton.

Campbell, Alexander, William Kimbrough Pendleton, and A.W. Campbell. 1856. The Millennial Harbinger. Vol. 6: W.K. Pendleton.

Carwardine, Richard. 1993. Evangelicals and Politics in Antebellum America. Knoxville: University of Tennessee Press.

Cummins, D. Duane. 1987. The Disciples Colleges: A History. St. Louis: CBP Press.

De Tocqueville, Alexis. 1839. Democracy in America. Translated by Henry Reeve. New York: George Adlard.

Earle, Jonathan H. 2005. Jacksonian Antislavery and the Politics of Free Soil, 1824-1854. Chapel Hill: University of North Carolina Press.

Fife, Robert. 1960. Alexander Campbell and the Christian Church in the Slavery Controversy. Ph.D. dissertation, Indiana University, Bloomington, IN, USA.

Foner, Eric. 1995. Free Soil, Free Labor, Free Men: The Ideology of the Republican Party before the Civil War with a New Introductory Essay. Cary: Oxford University Press.

Foster, Douglas A. 2004. The Encyclopedia of the Stone-Campbell Movement. Grand Rapids: Eerdmans Publishing Company.

Fuller, Corydon E. Reminiscences of James A. Garfield: With Notes Preliminary and Collateral. Colorado Springs: Standard Publishing Company.

Garrett, Leroy. 2002. The Stone-Campbell Movement: The Story of the American Restoration Movement. Abilene: College Press Pub.

Hobbs, Robert Wilson. 1899. The Drift. Indianapolis: The Senior Class of Butler College.

Kondelik, John P. 1993. Butler University and the Dream of Distinction. Ann Arbor: University of Michigan.

Madison, James H. 2014. Hoosiers: A New History of Indiana. Bloomington: Indiana University Press.

Martin, John Bartlow. 1947. Indiana: An Interpretation. Bloomington: Indiana University Press.

McPherson, James M. 1997. Afterward. In Religion and the American Civil War. Edited by Randall M. Miller, Harry S. Strout and Charles Reagan Wilson. New York: Oxford University Press.

Miller, Randall M., Harry S. Stout, and Charles Reagan Wilson, eds. 1998. Religion and the American Civil War. New York: Oxford University Press.

Nevins, Allan. 1938. The Gateway to History. New York: D. Appleton-Century Company.

Nolan, Jeannette Covert. 1943. Hoosier City. New York: Messner, J. Incorporated.

Noll, Mark A. 2006. The Civil War as a Theological Crisis. Chapel Hill: University of North Carolina Press.

North-Western Christian University. 1856a. Daily State Sentinel, July 1.

North-Western Christian University. 1856b. Daily State Sentinel, June 26.

Pierson, Michael D. 1993. Between Antislavery and Abolition: The Politics and Rhetoric of Jane Grey Swisshelm. Pennsylvania History: A Journal of Mid-Atlantic Studies 60: 305-21.

Payton, Robert L. 1988. Philanthropy: Voluntary Action for the Public Good. New York: American Council on Education/Macmillan Publishing Company.

Robbins, Kevin C. 2006. The Nonprofit Sector in Historical Perspective: Traditions of Philanthropy in the West. In The Nonprofit Sector: A Research Handbook. Edited by W. W. Powell and R. Steinberg. New Haven: Yale University Press.

Seay, Scott. 2015. By Thad Austin. Indianapolis: Christian Theological Seminary, December 1.

Smith, J., O. Butler, and T. Wiley. 1863. Is Slavery Sinful? Indianapolis: H. H. Dodd \& Co., Printers. 
The Stormy Question: Christian Churches and the Slavery Issue. Disciples of Christ Historical Society. Available online: http:/ / portal.sliderocket.com/AQRSO/The-Stormy-Question-REV-NAV (accessed on 1 July 2018). Thomas, Corban Dean. 2005. Slavery, a Colossal Crime: A Religious and Political Biographical Thesis of Ovid Butler (1801-1881). Johnson City: Emmanuel School of Religion.

Waller, George M. 2006. Butler University: A Sesquicentennial History. Bloomington: Indiana University Press.

Watkins, K. 2001. Christian Theological Seminary, Indianapolis: A History of Education for Ministry. Carmel: Guild Press of Indiana.

Wesley, Timothy L. 2013. The Politics of Faith during the Civil War. Baton Rouge: Louisiana University State Press.

(C) 2018 by the author. Licensee MDPI, Basel, Switzerland. This article is an open access article distributed under the terms and conditions of the Creative Commons Attribution (CC BY) license (http:/ / creativecommons.org/licenses/by/4.0/). 